\title{
Antioxidant Activity of Papaya Peel and Developed Chapathis
}

\author{
C.S. Pavithra ${ }^{1}$, S. Suchiritha Devi ${ }^{*}$, W. Jessie Suneetha ${ }^{1}$, \\ B. Anila Kumari ${ }^{1}$ and Ch.V. Durga Rani ${ }^{2}$ \\ ${ }^{1}$ Department of Foods and Nutrition, Professor Jayashankar Telangana State Agricultural \\ University, Rajendranagar, Hyderabad - 500 030, Telangana, India \\ ${ }^{2}$ Department of Molecular Biology and Biotechnology, Institute of Biotechnology, Professor \\ Jayashankar Telangana State Agricultural University, Rajendranagar, Hyderabad - 500030 , \\ Telangana, India \\ *Corresponding author
}

\section{A B S T R A C T}

\section{Keywords}

Papaya peel, Phytochemical

screening, Total phenols, Flavonoids,

Antioxidants

Article Info

Accepted:

07 September 2017

Available Online:

10 November 2017
Consumption of natural bioactive compounds and dietary fiber offers health benefits and protection against various diseases. The by-products of papaya is approximately $20-25 \%$ of fruit weight and it is a good source of minerals, fiber and phenolic compounds that have a wide range of pharmacological activities. The results of present study revealed that phenols, flavonoid and antioxidant activity of papaya peel paste and powder. As the concentration of the processed papaya peel increased, the antioxidant activity increased in comparison to control chapathis. The $\mathrm{IC}_{50}$ values were 0.11 and $0.18 \mathrm{mg} / \mathrm{ml}$ for PSP and PPP. The control chapathi, PSC and PPC had $\mathrm{IC}_{50}$ of $0.60,0.37$ and $0.35 \mathrm{mg} / \mathrm{ml}$ respectively indicating that heat treatment did not have much effect on papaya peel.

\section{Introduction}

Currently papaya peel is discarded which contribute to environment pollution. The agro-industrial by-products are good sources of bioactive compounds and the exploitation of these abundant and low-cost renewable resources can be used to develop new products with uses in pharmaceutical and food industries (Brasi et al., 2014). They are good sources of minerals, fibre and phenolic compounds with antiviral, antibacterial and cardio protective properties. Phytochemicals act as an antioxidant and anti-inflammatory agents playing vital role in detoxification of harmful and deleterious chemicals from human body (Djilas et al., 2009).

Papaya is known for its hydrogen peroxide and hydroxyl radical scavenging activity along with guava, water melon, grapefruit and kiwi fruit (Murcia et al., 2001). Phenolic compounds are important fruit constituents as they inactivate free radicals as well as prevent decomposition of hydro peroxides into free radicals (Maisuthisakul et al., 2007). 


\section{Materials and Methods}

Ripe papaya and other ingredients were procured from local market of Hyderabad. Papaya peel paste (PSP) and papaya peel powder (PPP) was prepared as procedure given by (Pavithra et al., 2017). Chapathis were prepared by the method as reported by (Cheng and Bhat, 2015).

Preliminary phytochemical screening, Phenols, Flavonoids and antioxidant activity of PSP, PPP and developed chapathis

The phytochemical screening was carried out as per the procedure given by Harbourne (1993). Total phenolic compounds were determined according to a modified method of Slinkard and Slingleton, (1997).

Total flavonoid content of samples were done as per the procedure given by Meda et al., (2005). Free radical scavenging assay by DPPH method as described by Dorman et al., (2004).

\section{Results and Discussion}

PPP, PSP and developed chapathis were screened for phytochemical components as given in table 1. Results of present study showed that the methanol extract of control chapathi contained carbohydrates, proteins, and amino acids. The methanol extract of PPP contained fats and oils.

The methanol extract of PPP, PSP, PPC (peel powder added chapathi) and PSC (peel paste added chapathi) contained carbohydrates, proteins, alkaloids (Mayer's test) flavonoid, terpenoids, cardiac glycosides, phenols and tannins. PPP, PSP, PPC and PSC lacked in fixed oils and fats, phlobatinins, steroids, saponins and quinones. The alkaloids, flavanoids, terpenoids, cardiac glycosides, phenols and tannins were present in developed chapathis compared to control sample due to incorporation of processed papaya peel.

\section{Total phenolic and flavonoid content}

The presence of phenolic compound affects the sensory qualities of plant-derived processed foods including taste, colour and texture. Flavonoids represent the most common group of plant phenolic compounds which influences the flavour and colour of fruits and vegetables (Akyol et al., 2016).Phenolic compounds such as tannins, flavonoids are considered to be the major contributors to the antioxidant capacity of plants. These antioxidants also possess diverse biological activities, such as antiinflammatory, anti-atherosclerotic and anticarcinogenic activities (Mala and Kurian, 2016).

In this study the phenolic and flavonoid content of PSP was 169.36 and $36.80 \mu \mathrm{g} / \mathrm{ml}$. PPP contains phenolic and flavonoid content of 108.53 and $24.42 \mu \mathrm{g} / \mathrm{ml}$ and 0.028 to $5.07 \mu \mathrm{g} / \mathrm{ml}$ for chapathis. The value added chapathi showed increase in Phenolic and flavonoid content in comparison with control chapathi. There was a significant difference $(\mathrm{p}<0.05)$ in the phenolic and flavonoid content of the chapathis. The phenolic and flavonoid contents were decreased in drying of papaya peel. Percentage change in phenolic and flavonoid content of developed chapathis was given in figure 1 .

The phenolic content diamond cookies with mango peel powder were $6.66 \mathrm{mg} / \mathrm{g}$ catechol equivalents. Although there may be some loss during processing there was increase in the phenolic, flavonoid and DPPH antioxidant activity of the diamond cookies prepared by adding mango peel powder due to addition at $15 \%$ level (Nisha and Bhatnagar, 2014). 
Table.1 Phytochemical screening of PPP, PSP, control and developed chapathis

\begin{tabular}{|c|c|c|c|c|c|c|c|}
\hline \multirow[t]{2}{*}{ S. No. } & \multirow[t]{2}{*}{ Phytochemicals } & \multirow[t]{2}{*}{ Test } & \multirow[t]{2}{*}{ PPP } & \multirow[t]{2}{*}{ PSP } & \multicolumn{3}{|c|}{ Chapathis } \\
\hline & & & & & Control & PPC & $\overline{\text { PSC }}$ \\
\hline 1 & Carbohydrate & Molisch test & + & + & + & + & + \\
\hline 2 & Alkaloids & Mayer's test & + & + & - & + & + \\
\hline & & Wagner's test & - & - & - & - & - \\
\hline & & Hager's test & - & - & - & - & - \\
\hline 3 & Proteins & Kjeldhal method & + & + & + & + & + \\
\hline 4 & Amino acids & Ninhydrin test & - & - & + & + & + \\
\hline 5 & Flavanoids & With $\mathrm{NH}_{3}$ solution & + & + & - & + & + \\
\hline 6 & $\begin{array}{l}\text { Fixed oils and } \\
\text { fats }\end{array}$ & Foam test & + & - & - & - & - \\
\hline 7 & Terpenoids & - & + & + & - & + & + \\
\hline 8 & $\begin{array}{l}\text { Cardiac } \\
\text { glycosides }\end{array}$ & - & + & + & - & + & + \\
\hline 9 & Steroids & $\begin{array}{l}\text { Liebermann- Buchard } \\
\text { test }\end{array}$ & - & - & - & - & - \\
\hline 10 & Saponins & Foam test & - & - & - & - & - \\
\hline 11 & Tannins & $\mathrm{FeCl}_{3}$ test & + & + & - & + & + \\
\hline 12 & Phlobatinins & With Conc. HCl & - & - & - & - & - \\
\hline 13 & Phenols & $\mathrm{FeCl}_{3}$ test & + & + & - & + & + \\
\hline & & Liebermann's test & + & + & - & + & + \\
\hline 14 & Quinones & With Conc. $\mathrm{HCl}$ & - & - & - & - & - \\
\hline
\end{tabular}

Note: All screening tests were carried out in triplicates.

Control: $100 \%$ wheat flour chapathi

PPC: $10 \%$ PPP incorporated chapathi

PSC: $15 \%$ PSP incorporated chapathi

PPP: Papaya peel powder

PSP: Papaya peel paste

Fig.1 Percentage change in phenolic and flavonoid content of developed chapathis

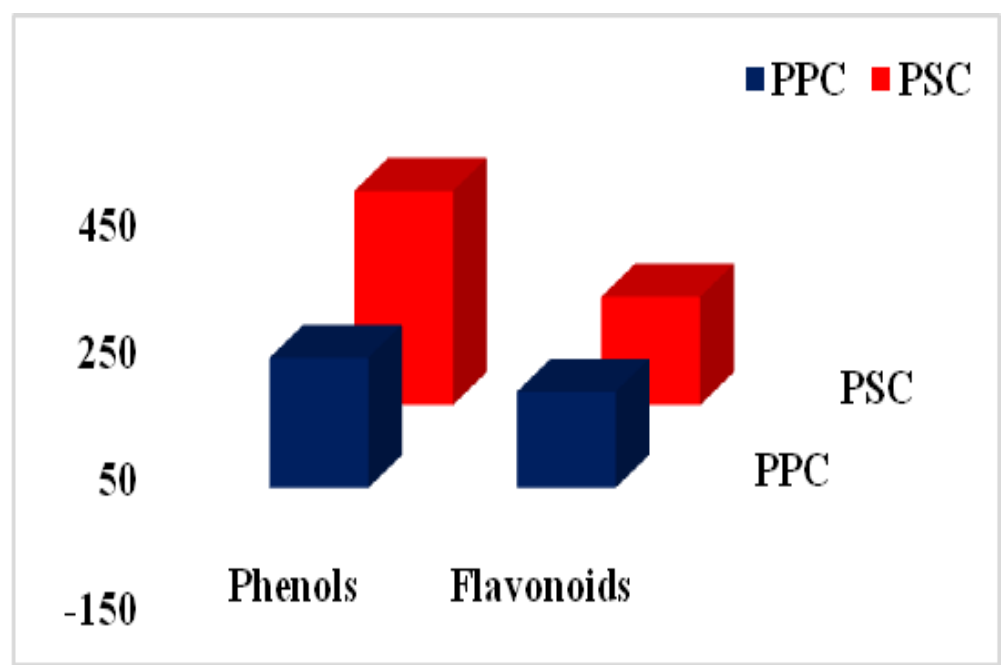




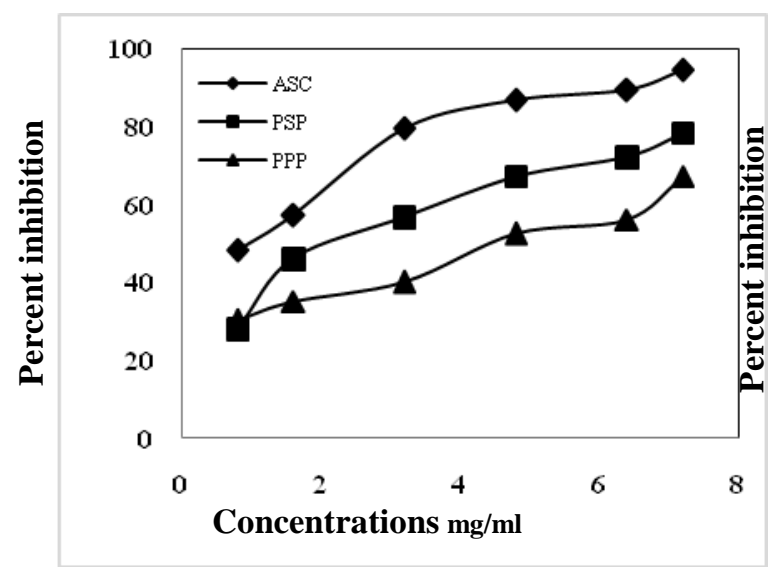

Fig.2 Percentage scavenging activity peel samples

Free radical scavenging assay by DPPH method

In the present study, the free radical scavenging potentials of the extracts at different concentrations were tested to deduce the $\mathrm{IC}_{50}$ value and lower the values better the scavenging activity. The total phenol and flavonoid contents in the PSP and PPP extracts could be responsible for the observed DPPH radical scavenging activity.

The percentage scavenging activity of PSP and PPP samples by DPPH method was given in figure 2 and percentage scavenging activity of control, PSC and PPP samples were given in figure 3 .

The $\mathrm{IC}_{50}$ were 0.11 and $0.18 \mathrm{mg} / \mathrm{ml}$ for PSP and PPP. The control chapathi, PPC and PSC had $\mathrm{IC}_{50}$ of $0.60,0.38$ and $0.35 \mathrm{mg} / \mathrm{ml}$ respectively. The increase in the antioxidant activity of PPC was $57.89 \%$ and for PSC it was $65.78 \%$.It can be concluded that PSC chapattis had the higher potency than PPC chapattis and both the developed chapattis had free radical scavenging activity than control chapathi. Similarly the antioxidant activity of $92.7 \%$ was in pomegranate peels, $75.9 \%$ in lemon peels and $71.4 \%$ was found in orange peels (Singh and Immanuel, 2014).

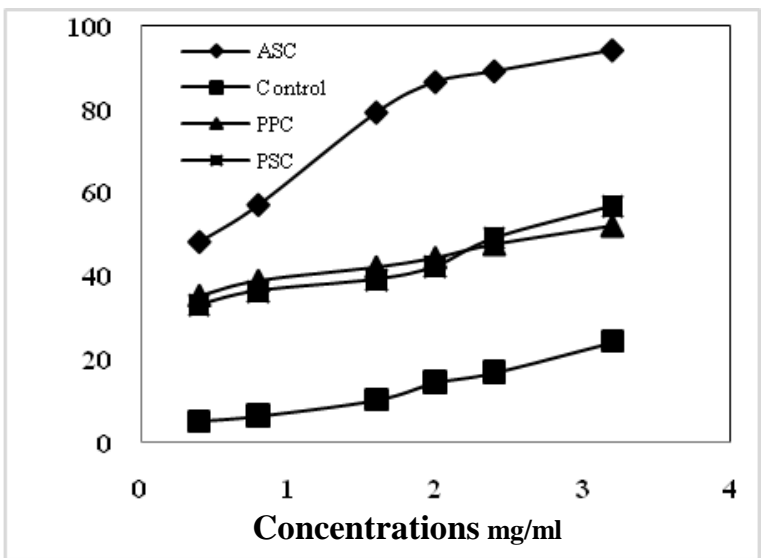

Fig.3 Percentage scavenging of activity of developed chapathis

The results revealed that the addition of PPP and PSP extract to DPPH solution caused a rapid decrease in $\mathrm{IC}_{50}$ values as indication to its good scavenging activity. The results indicated that PPP and PSP has a noticeable effect on scavenging free radicals. This could be attributed to its high content of phenols, tannins, $\beta$ carotene and flavanoids. The $\mathrm{IC}_{50}$ values were 0.11 and $0.18 \mathrm{mg} / \mathrm{ml}$ for PSP and PPP. The control chapathi, PPC and PSC had $\mathrm{IC}_{50}$ of $0.60, \quad 0.37$ and $0.35 \mathrm{mg} / \mathrm{ml}$ respectively.

\section{References}

Akyol, H., Riciputi, Y., Capanoglu, E., Caboni, M.F and Verardo, V. 2016. Phenolic Compounds in the Potato and Its By-products: An Overview. International Journal of Molecular Science. 17: 1-19.

Brasi, I.M., Silva, L.M.R.D., Figueiredo E.A.T.D., Ricardo, N.M.P.S., Vieira, I.G.P., Figueiredo, R.W.D., Gomes, C.L. Quantification of bioactive compounds in pulps and by-products of tropical fruits from brazil. Journal of Food Chemistry. 143: 398-404.

Cheng, Y. F. and Bhat, R. 2015. Physicochemical and sensory quality evaluation of chapathi (Indian flat 
bread) produced by utilizing underutilized jering (Pithecellobium jiringa Jack.) legume and wheat composite flours. International Food Research Journal. 22(6): 2244-2252.

Djilas, S., Brunet, C. J and Cetkovic, G. 2009. By products of fruits processing as a source of phytochemicals. Chemical Industry and Chemical Engineering Quarterly. 15(4): 191-202.

Dorman, H.J., Bachmayer, O., Kosar, M and Hiltunen, R. 2004. Antioxidant properties of aqueous extracts from selected laminaceae species grown in Turkey. Journal of Agricultural and Food Chemistry. 52: 762-770.

Harborne, J.B. 1993. Phytochemistry. Academic press, London. 89-131.

Maisuthisakul, P., Suttajit, M. and Pongsawatmanit, R. 2007. Assessment of phenolic content and free radical scavenging capacity of some Thai indigenous plants. Journal of Food Chemistry. 100: 1409-1418.

Mala, K.S and Kurian, A.E. 2016. Nutritional composition and antioxidant activity of pumpkin wastes. International Journal of Pharmaceutical, Chemical and Biological Sciences. 6(3): 336-344.

Meda, A., Lamicn, C.E., Romito, M.,
Millogo, J and Nacoulma, O.G. 2005. Determination of the total phenolic, flavonoid and proline contents in Burkina fasan honey, as well as their radical scavenging activity. Food chemistry. 91: 571-577.

Murcia, M.A., Jimenez, A.M and MartinezTome, M. 2001. Evaluation of the antioxidant properties of Mediterranean and tropical fruits compared with common food additives. Journal of Food Protection. 64: 2037-2046.

Nisha and Bhatnagar, V. 2014. Utilization of mango peels as a source of phytochemicals in biscuits. Indian Journal of Extension Education and Rural Development. 22: 51-55.

Pavithra, C.S., Devi, S.S., Suneetha, W. J. and Rani, V.D. 2017. Nutritional properties of papaya peel. The Pharma Innovation Journal. 6(7): 170-173.

Singh, S and Immanuel, G. 2014. Extraction of antioxidants from fruit peels and its utilization in paneer. Journal of Food Processing and Technology. 5 (7): 2-5.

Slinkard, K and Singleton, V.L. 1997. Total phenol analysis, automation and comparison with manual methods. American Journal of Ecology and Viticulture. 28:49-55.

\section{How to cite this article:}

Pavithra, C.S., S. Suchiritha Devi, W. Jessie Suneetha, B. Anila Kumari and Durga Rani, Ch.V. 2017. Antioxidant Activity of Papaya Peel and Developed Chapathis. Int.J.Curr.Microbiol.App.Sci. 6(11): 636-640. doi: https://doi.org/10.20546/ijcmas.2017.611.076 